\title{
Sinkhole formation hazard assessment
}

\author{
Piotr Strzałkowski ${ }^{1}$ (1)
}

Received: 25 September 2018 / Accepted: 15 December 2018 / Published online: 20 December 2018

(c) The Author(s) 2018

\begin{abstract}
Sinkholes forming as a result of loss of stability of shallow voids of natural or anthropogenic origin (mining activity) pose a serious hazard to buildings and infrastructure and especially to the inhabitants of the area. The paper presents an example of the verification of the author's mathematical model of forecasting the formation of sinkholes. The verification was performed with the use of a computer program for a case that was strictly compliant to the model assumptions. The sinkhole has formed above a working located at the depth of $54 \mathrm{~m}$, outside the area of bifurcations or crossings with another gallery. The working was not influenced by mining exploitation, which means that the analysed case fully met the assumptions of the adopted mathematical model. The calculations of the sinkhole dimensions were also carried out, providing results that correspond to the actual conditions. The calculations and the performed analysis have confirmed the usability of the proposed model.
\end{abstract}

Keywords Sinkhole hazard · Investment safety

\section{Introduction}

Sinkholes constitute a significant hazard to the public safety in built-up areas (Brinkmann et al. 2008). Their formation may cause collapses of structures and high material losses due to the destruction of buildings, roads and railways (Xua et al. 2017). The financial costs of dealing with the consequences of sinkholes are often very high. According to (Kuniansky et al. 2015), in the years 2006-2010, insurance companies in Florida received over 24.5 thousand claims for damages due to the formation of sinkholes, for a total sum of 1.4 billion dollars. One of the most common causes of formation of sinkholes is the collapse of voids which naturally occur (karst phenomena) in carbonate rocks (Gutiérrez et al. 2013). The highest number of such sinkholes is observed in the American Florida state (Xiao et al. 2016).

The results of the study (Xiao et al. 2016) indicate the relationship between the amount of atmospheric precipitation (and thus the water level in wells, reflecting the water level in the rock mass) and the number of newly formed sinkholes. The density of occurrence of sinkholes increases in a linear manner along with the rate of water being fed to

Piotr Strzałkowski

piotr.strzalkowski@polsl.pl

1 Faculty of Mining and Geology, Silesian University of Technology, Akademicka 2, 44-100 Gliwice, Poland the aquifers and the differences in water table levels. The authors have decided that it is necessary to gain a better knowledge of the correlation between the formation of sinkholes and the local changes in hydrogeological conditions to be able to take up actions aimed at the reduction of the probability of formation of sinkholes. Although a single sinkhole may be considered an event of local significance in terms of the scale of the phenomenon, it is of extreme importance in planning a given investment. The authors have also expressed their opinion that the combined effects of climatic conditions (atmospheric precipitation) and the urban sprawl shall result in the fact that the formation of sinkholes shall also constitute a problem in future. This is of significance in case of spatial planning.

Various activities are conducted to assess the hazard level of sinkhole formation. In the paper by Gutiérrez et al. (Gutiérrez et al. 2013), the necessity of multidimensional identification of geological conditions in which the sinkholes have formed was indicated (field research: speleological exploration, boreholes, geomorphological mapping, information provided by citizens, historical data). Based on the above, the probability of sinkhole formation is estimated, assuming that new sinkholes would be formed in conditions similar to the ones accompanying the previous formations. At a later stage, maps of the areas with a specified sinkhole formation probability are developed. Such maps are highly useful in preparing land use plans. The design of adequate 
structures of buildings, protecting them against damage due to the formation of sinkholes, has also been considered.

The preparation of maps of usability of sinkhole areas for development has also been considered in the paper by Bathrellos et al. (Bathrellos et al. 2012). The area of the study encompassed the Trikala Prefecture in central Greece, while the geological, geomorphological and geographical conditions, as well as natural hazards were taken into consideration in the determination of usability. The factors used in the analyses were correlated using the AHP method and implemented in the GIS system, which allowed for the development of maps. Thus, the rational planning of development of the area both for residential and industrial buildings as well as parks or recreational areas was possible.

Similar factors were also considered when creating maps of susceptibility to formation of sinkholes and thus the usability for development in the state of Maryland in USA (Doctor et al. 2008).

A full list of factors causing the loss of stability of karst voids and thus the formation sinkholes in the area of Athens may be found in the paper by Papadopoulou-Vrynioti et al. (Papadopoulou-Vrynioti et al. 2013). While studying the probability of formation of sinkholes, the authors analysed natural factors (surface inclination, hydrographic conditions, lithology and tectonics as well as seismic activity) and anthropogenic factors (road network, land development). An innovative method was proposed, relating the occurrence of a sinkhole with the assessment of seismic hazard expressed by means of PGA. The factors that contribute to the greatest degree to the formation of sinkholes were determined and a map of susceptibility of karst formations with a division into four classes was developed by applying logistic regression.

Geophysical methods of detecting voids in the rock mass have been found to be helpful in the assessment of sinkhole hazard, which was noted in the paper by Kaufmann (Kaufmann 2014). The work by Ezersky et al. (Ezersky et al. 2013) also exhibited the results of the research aimed at the assessment of the sinkhole formation hazard. The research, conducted by means of SRFR, ERT and gravimetric methods, was positively verified by drilling boreholes.

The papers referred to above concerned the hazard level of formation of sinkholes due to the collapse of karst caverns-naturally-occurring voids in the rock mass. The research encompassed relatively large areas and as such, constituted a global approach to the assessment of this hazard. At the same time, it should be noted that the necessity to perform small-scale analyses of sinkhole formation hazard has also been indicated (Xiao et al. 2016). An example of such an assessment for a single cavern may be found in Baryakh and Fedoseev (Baryakh and Fedoseev 2011), in which the range of plastic deformations around the cavern was determined by means of numerical methods. Subsequently, the conditions for the formation of sinkholes were formulated in a manner similar to the methods described in the paper by Chudek et al. (Chudek et al. 1988).

The causes of formation of sinkholes are not only related to natural processes, but also to human activity. The above includes, i.a. the leakages of rainwater sewage systems (occurring especially during heavy rainfalls). This leads to the formation of sinkholes in the area of highways (Mellett and MacCarillo 1996) or buildings (Scarborough 1996).

In Upper Silesia, one of the largest functioning coal districts in modern Europe, the problem of formation of sinkholes is connected with the loss of stability of mine shafts that were liquidated improperly, and especially in cases of loss of stability of shallow workings. In practice, sinkholes are most commonly formed in the case of roadway collapses (the ones that were not liquidated, left with the timber roof support) at the depth of 80-100 m.

Sinkhole formation is related to the main risk factors provided in the paper by Malinowska and Matonóg (Malinowska and Matonóg 2017): “'depth of mining extractions, density of underground drifts, thickness of loose overburden, the overlapping mining panels' edges in horizontal projection, the height of secondary void, the presence of mining shafts and locations exposed to traffic-induced vibrations.'

The assessment of the risk of formation of sinkholes may be difficult for numerous reasons. Due to the uncertainty of information, the Chudek-Olaszowski method is often used for making predictions. The method allows for defining the probability of sinkhole formation (Chudek et al. 1988). As in other countries, the analysis is also carried out using numerical methods (Strzałkowski and Tomiczek 2015). In this paper, the verification of the analytical method of predicting sinkholes has been shown. The method is based on the theory of the pressure arch (Sałustowicz 1958). This theory was broadly described in the paper by Strzałkowski (Strzałkowski 2015).

Similar to the methods referred above, the presented method, its verification and the determination of sinkhole dimensions may be used for the assessment of the sinkhole formation hazard. Such assessment allows to make correct decisions regarding the development of small areas. At the same time, it should be stated that analyses conducted for smaller areas are inherently more reliable. Using this method, a decision may be made whether a building could be raised in a given location or the location would serve better as a recreation area. Both in view of Polish and foreign professional literature, the problem is highly relevant and important for public safety.

The goal of the paper was to present and verify the deterministic method of forecasting sinkholes while giving consideration to their dimensions. The method allows to unequivocally confirm whether the sinkhole will or will not be formed. This is because it was assumed that using the probability of sinkhole formation leads to making decisions 
regarding land development burdened with excessive risk or excessive caution.

\section{The methodology used in the paper}

The method of using the theory of the pressure arch for the purpose of predicting the formation of sinkholes has been presented in the paper by Strzałkowski (Strzałkowski 2015). The pressure arch is being created when $\sigma_{x \max } \geqslant R_{r}$, that is, when the stress in the roof of working in the $x-\sigma_{x}$ direction is not lower than the rock tensile strength $-R_{r}$. In any other case, the working remains stable.

According to the solution presented above, the vertical cross-section area of the part of the required $P_{\mathrm{e}}$ loosened zone (the stripped area in Fig. 1) equals:

$P_{\mathrm{e}}=S_{1}-\frac{w l}{2}+2 \cdot S_{2}$

where $S_{1}$ the cross-section area of the upper part of the fracture ellipse (the loosened zone) $S_{1}=\frac{\pi a b}{8}, w, l$ height and width of the excavation, $a, b$ axes of the stress relieved zone ellipse:

$S_{2}=\frac{1}{2} \int_{0}^{k}\left[\frac{b}{2} \cos t \cdot \frac{a}{2} \cos t-\frac{a}{2} \sin t \cdot \frac{b}{2}(-\sin t)\right] \mathrm{d} t-\frac{w l}{8}=\frac{a b k-w l}{8}$

$k=\pi \alpha / 180^{\circ} k=\frac{\pi}{180^{\circ}} \cdot \arctan \frac{w}{l}$.

Therefore,

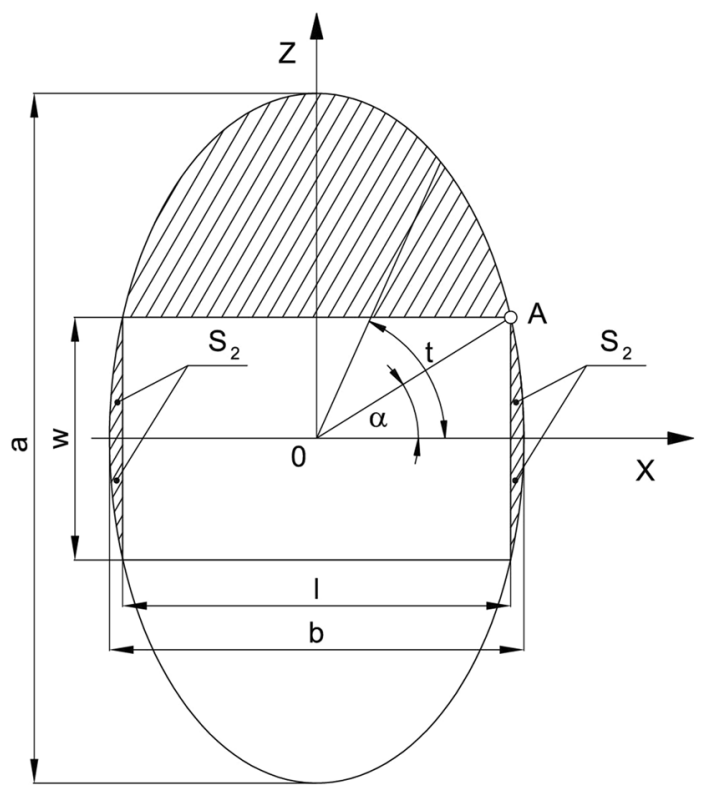

Fig. 1 The loosened zone around the void (working) in the rock mass (Strzałkowski 2015)
$P_{\mathrm{e}}=\frac{a b(\pi+2 k)-6 w l}{8}$

According to the paper from Strzałkowski (Strzałkowski 2015), it can be presumed that when a collapse occurs, the rocks of the loosened zone move in the direction of the void, thus filling the working. Assuming that:

$P_{1}=P_{\mathrm{e}} \cdot k_{r}$

$P_{2}=P_{\mathrm{e}}+w \cdot l$

where $k_{r}$ rock loosening coefficient, two cases may be distinguished:

- when $P_{1}=P_{2}$, the void is subject to self-backfilling and the rocks from the loosened zone fill it completely;

- when $P_{1}<P_{2}$, a secondary void is formed around the top of the loosened zone. Its volume equals the subtraction of the surface areas $P_{2}-P_{1}$. When the loosened zone related to the secondary void reaches the overburden layer, a sinkhole is formed.

The iterative method of determining the dimensions of the secondary void and the algorithm (the computer program) that allows to determine whether the sinkhole will occur have both been presented in the paper by Strzałkowski (Strzałkowski 2017). The next voids' shapes were approximated to the shape of a rectangle, while maintaining the correct proportions (the ratio of the sides of the rectangle) typical for workings (the primary void). In the paper by Strzałkowski (Strzałkowski 2015), formulas for determining sinkhole dimensions were presented, assuming that the sinkhole assumes a shape of a truncated funnel (with a flat bottom). In the paper by Strzałkowski (Strzałkowski 2017), the proposed method was verified, however, without providing for the prediction of the sinkhole's dimensions. The verification shown herein includes such a prediction, because in the considered case the information on the lithological section was accessible along with the information regarding the cone-shaped sinkhole's dimensions. The calculation of the size of this kind of sinkhole requires using adequate formulas. Let us assume that the top of the primary or secondary void reaches the top of compact rock mass (Fig. 2). Assuming that the void is completely filled with the loose rocks of the overburden, the volume of the void equals the volume of the cone-shaped sinkhole. Based on the above, the following may be assumed:

The surface area of the void:

$P_{p}=w \cdot l$

The surface area of the sinkhole:

$P_{z}=0.5 \cdot w_{z} \cdot(l+2 \cdot x)=0.5 \cdot w_{z} \cdot\left(l+2 \cdot w_{z} \cdot \operatorname{tg} \varphi\right)$

where $\phi$ the angle of internal friction of the loose overburden, $w_{z}$-the depth of the sinkhole, $x=w_{z} \operatorname{tg} \phi$. 


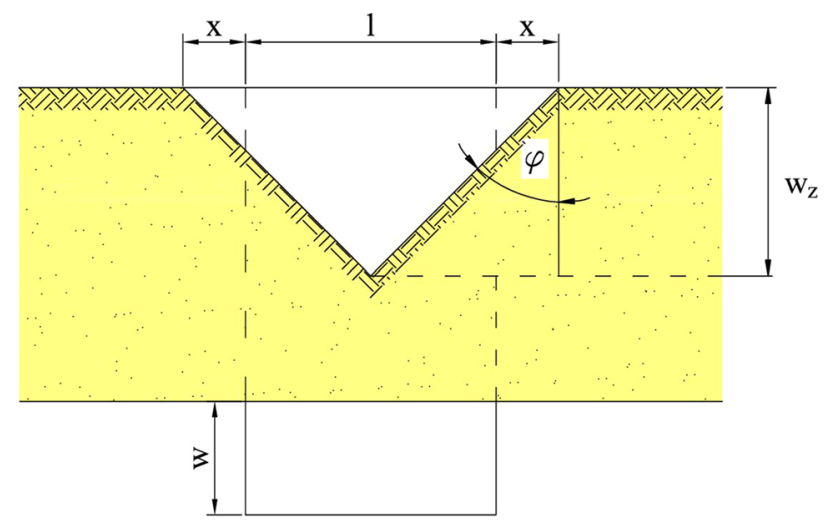

Fig. 2 Schematic drawing used for calculating the size of the coneshaped sinkhole

The depth of the sinkhole can be easily calculated comparing the Eqs. (4) and (5), which reduces the problem to solving a trinomial square. Of course, only a positive value may be considered. The diameter of the sinkhole equals:

$d=l+2 \cdot x$

\section{The results of applying the model in the case in consideration}

In approximation, the surface of the subsidence area may be considered a horizontal plate located at an elevation of $220 \mathrm{~m}$ a.s.l. The area is not developed and is used as agricultural land-pastures and meadows. No watercourses exist in the area. The sinkhole has formed above a ventilation gallery that was $3.2 \mathrm{~m}$ high and $3.5 \mathrm{~m}$ wide, driven at the depth of $54 \mathrm{~m}$ counting from the bottom of the sinkhole. A schematic diagram depicting the location of the excavation and of the created sinkhole has been presented in Fig. 3. The rock mass consisted of an overburden of loose rocks of a total thickness of $48 \mathrm{~m}$. The overburden consisted of alternating layers of sand, clay, gravel with sand and crumbles of solid rocks. The quaternary formations are characterized by a high water content. Under the overburden, a marl layer was present exhibiting reduced strength parameters, due to the watering of the rock mass. The marls were of Neogene origin. No cracking network has formed in the rock mass, as no mining exploitation was conducted within the area. The lithological section of the rock mass has been presented in Fig. 4. As a result of the loss of stability of the ventilation gallery's roof support, a cone-shaped sinkhole was formed. The dimensions of the sinkhole were as follows: the diameter was $6.0 \mathrm{~m}$ and the depth was $3.0 \mathrm{~m}$. The time of its formation was relatively short—it took as little as around $2 \mathrm{~h}$. The sinkhole appeared

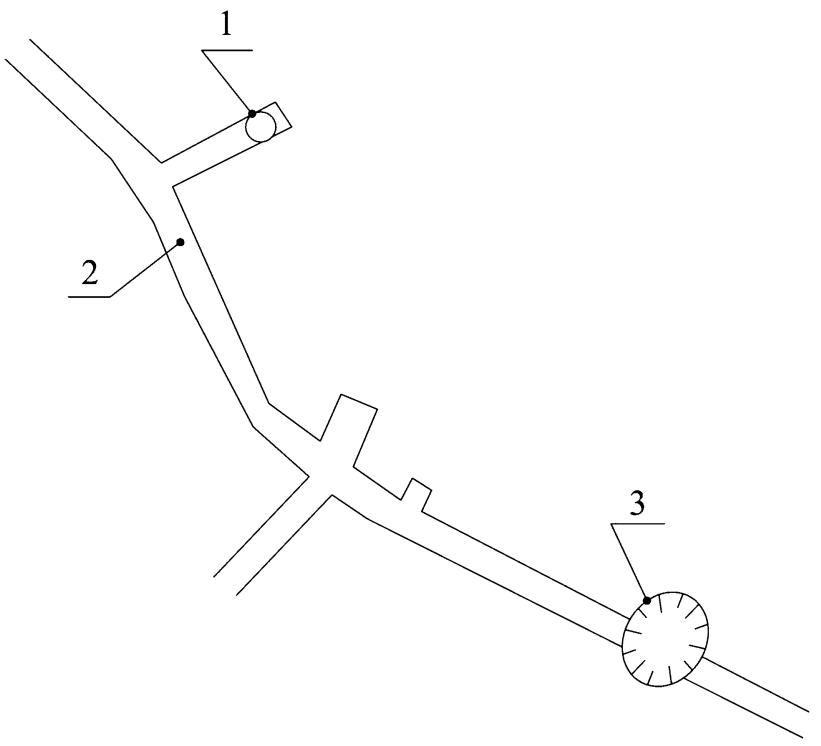

Fig. 3 Schematic diagram of the location of workings and the sinkhole, 1 -stowing borehole, 2-ventilation gallery, 3-sinkhole

in an agricultural area, and thus no tragic results followed. It should be noted that no mining works were being performed in the area of the ventilation gallery.
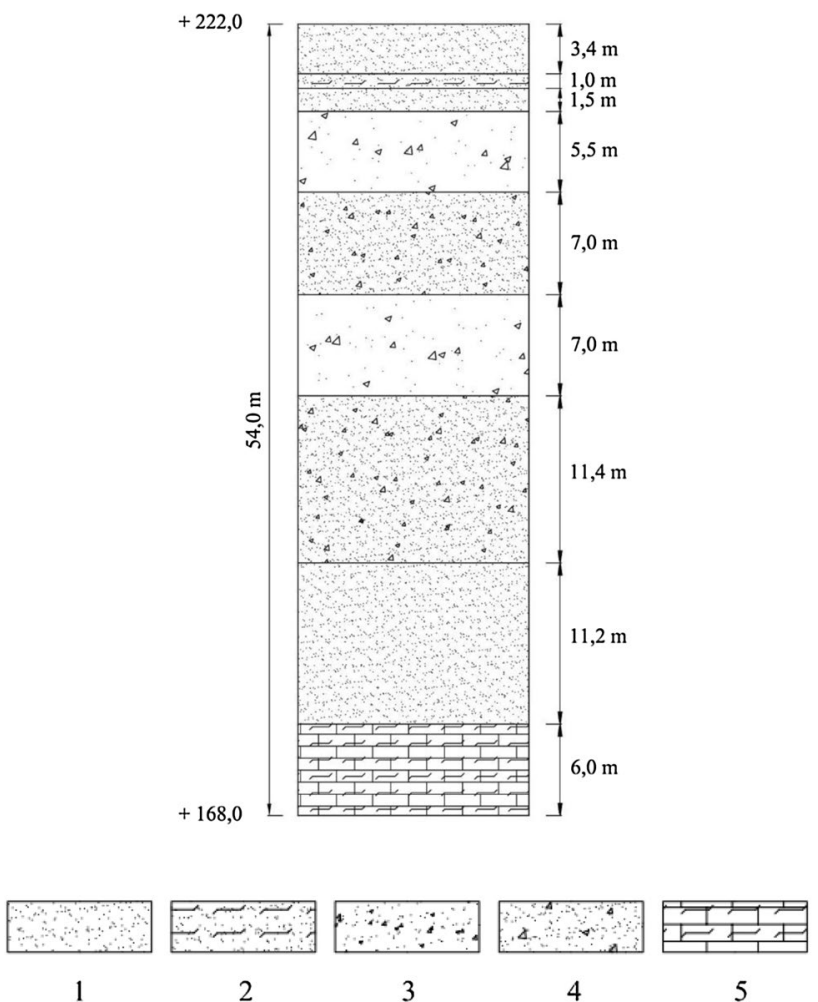

Fig. 4 The lithological section of the rock mass, 1-sand, 2-sandy loam, 3-gravel, 4-gravel with admixture of sand, 5-marl 
The computer program described in the paper by Strzałkowski (Strzałkowski 2017) was used for the calculations. The following values characterising the rock mass were assumed (Chudek 2010; Kidybiński 1982):

- tensile strength of the overburden layers $R_{r}=0 \mathrm{MPa}$,

- tensile strength of the marl layers $R_{r}=0.4 \mathrm{MPa}$,

- bulk density of the soft rocks $\gamma=0.027 \mathrm{MPa} / \mathrm{m}$

- bulk density of the marl $\gamma=0.025 \mathrm{MPa} / \mathrm{m}$

- the factor of rock loosening for marl $k_{r}=1.05$

- angle of internal friction of the overburden layers $\phi=23^{\circ}$.

The calculation results are presented in Fig. 5, exhibiting the working and the secondary voids that were formed as a result of stability loss. The dimensions and the location have also been depicted.

Based on the calculations, it may be assumed that the base of the shallowest secondary void (the last one that occurred before the sinkhole has formed) was at the depth of $51.31 \mathrm{~m}$ and the height of the void was $3.07 \mathrm{~m}$. Thus, the

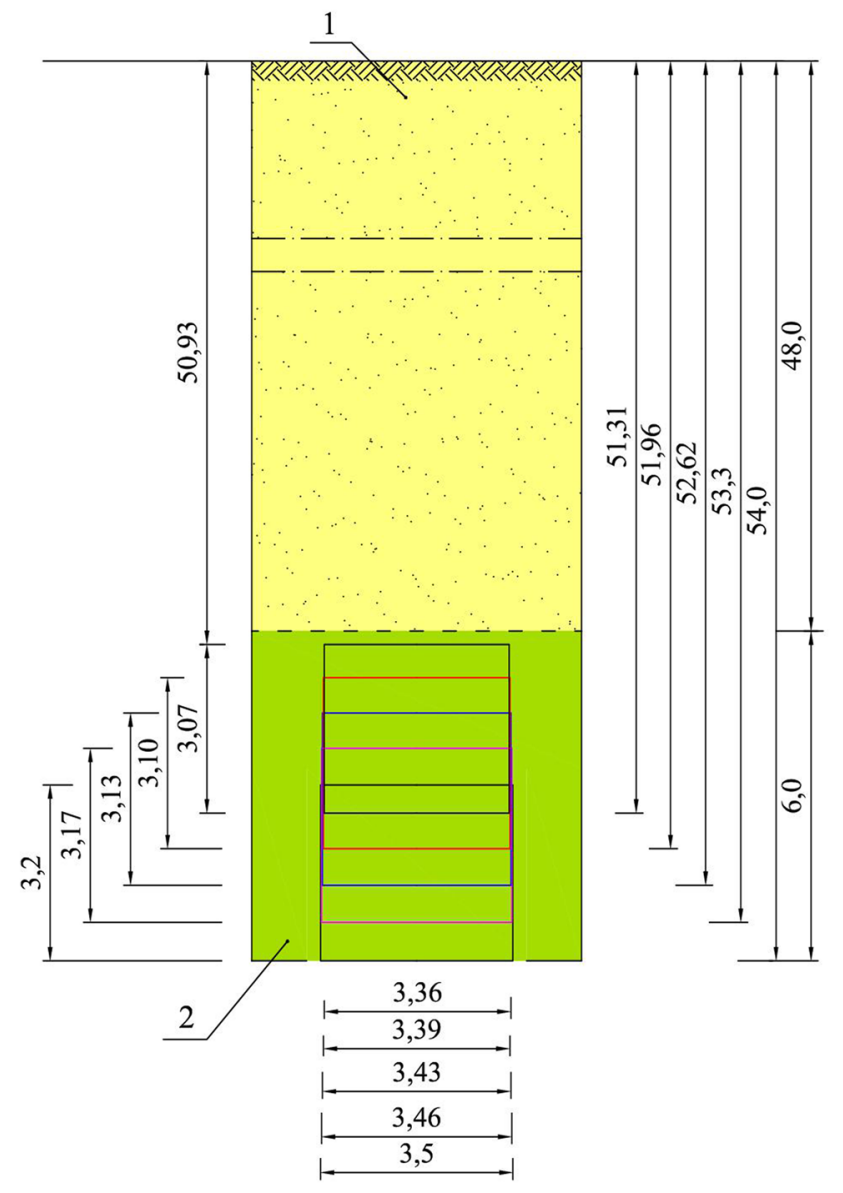

Fig. 5 The location and dimensions of the primary void (working) and the secondary voids, 1 -loose overburden, 2-compact rock mass top of the void was $0.24 \mathrm{~m}$ below the top of the marl layer. The length of the vertical half-axis of the fracture zone was $2.61 \mathrm{~m}$-Fig. 6. It may be assumed, using a slight simplification, that loose rocks were capable of filling the void of the height reduced by $0.24 \mathrm{~m}$, which resulted from the thickness of marl laying above the top of the secondary void. Assuming that the top of the secondary void was at the height of $2.83 \mathrm{~m}(3.07-0.24 \mathrm{~m})$, reaching the top of the marl layer, it may be calculated - using Eqs. (3) and (4) - that the dimensions of the sinkhole are as follows:

depth of the sinkhole $w_{z}=3.15 \mathrm{~m}$, diameter of the sinkhole $d=6.03 \mathrm{~m}$.

The results of the calculations were fully compatible with the actual observations.

\section{Conclusion}

An example of verification of a mathematical model of predicting the formation of sinkholes has been presented in this paper. This model is based on the assumption that an ellipse-shaped pressure arch appears around the void. The

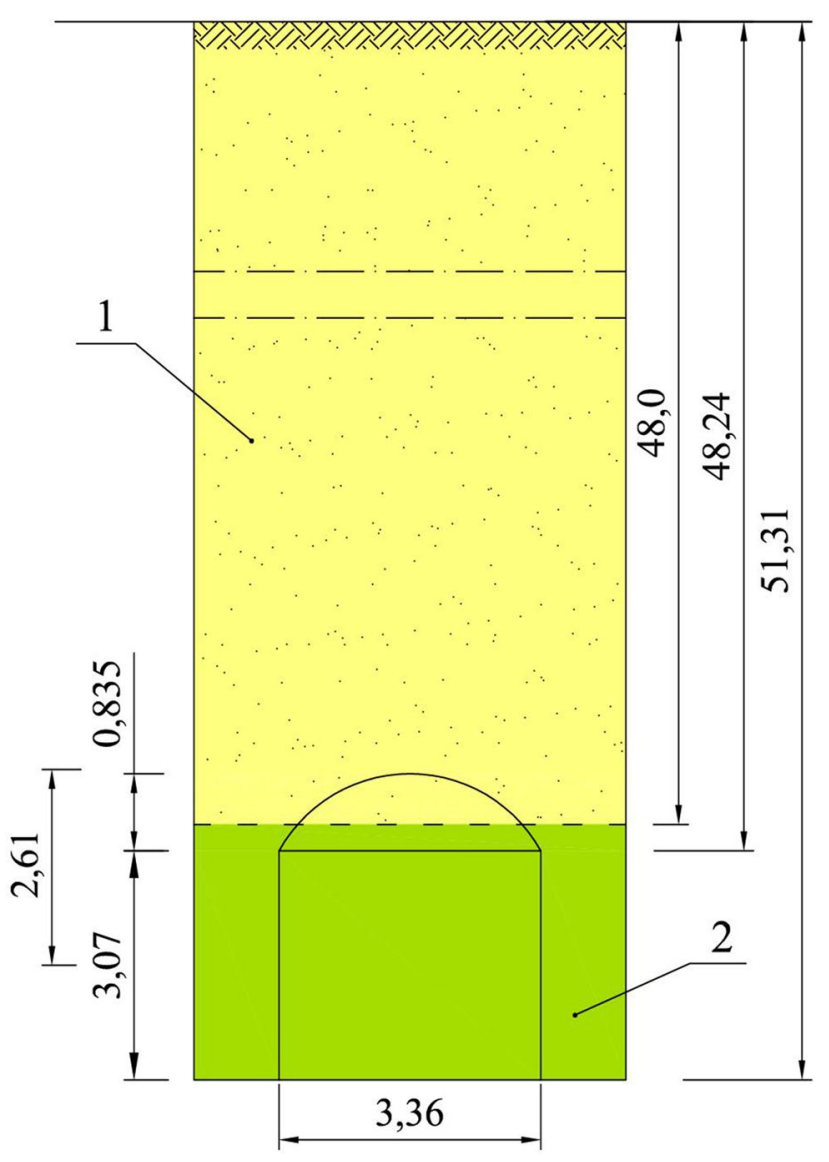

Fig. 6 Location of the last void causing the creation of a sinkhole, 1 -loose overburden, 2 - compact rock mass 
calculations were performed and analysed for the selected case of sinkhole formation. The calculations were performed using a computer program operating based on the assumption of the model that was being verified. The sinkhole has formed above a working located at the depth of $54 \mathrm{~m}$, outside any area of bifurcation or crossing with another gallery. The working was not influenced by any ongoing exploitation, which means that the analysed case fully met the assumptions of the adopted mathematical model. As part of the study, calculations of dimensions of the sinkhole were performed for the first time. The results fully corresponded to the actual dimensions of the deformation. The performed analysis has proven the usefulness of the proposed model.

Open Access This article is distributed under the terms of the Creative Commons Attribution 4.0 International License (http://creativeco mmons.org/licenses/by/4.0/), which permits unrestricted use, distribution, and reproduction in any medium, provided you give appropriate credit to the original author(s) and the source, provide a link to the Creative Commons license, and indicate if changes were made.

\section{References}

Baryakh AA, Fedoseev AK (2011) Sinkhole formation mechanism. J Min Sci 47(4):404-412

Bathrellos GD, Gaki-Papanastassiou K, Skilodimou HD, Papanastassiou D, Chousianitis KG (2012) Potential suitability for urban planning and industry development by using natural hazard maps and geological-geomorphological parameters. Environ Earth Sci 66(2):537-548. https://doi.org/10.1007/s12665-011-1263-x

Brinkmann R, Parise M, Dye MD (2008) Sinkhole distribution in a rapidly developing urban environment: Hillsborough County, Tampa Bay, Florida. Eng Geol 99(3-4):169-184

Chudek M (2010) Rock mass mechanics with basics of environment management in mining and post-mining areas. Wydawnictwo Politechniki Śląskiej, Gliwice (in Polish)

Chudek M, Janusz W, Zych J (1988) Study on diagnosis and prognosis of the formation of discontinuous deformation due to underground mining. Zeszyty Naukowe Politechniki Śląskiej, seria Górnictwo, vol. 141. Gliwice (in Polish)

Doctor KZ, Doctor DH, Kronenfeld B, Wong DWS, Brezinski DK (2008) Predicting sinkhole susceptibility in Frederick Valley, Maryland using geographically weighted regression. In: Proceedings of the 11th multidisciplinary conference on sinkholes and the engineering and environmental impacts of Karst 2008, vol 183. American Society of Civil Engineers, Geotechnical Special Publication, pp 243-256

Ezersky MG, Eppelbaum LV, Al-Zoubi A, Keydar S, Abueladas A, Akkawi E, Medvedev B (2013) Geophysical prediction and following development sinkholes in two Dead Sea areas, Israel and Jordan. Environ Earth Sci 70(4):1463-1478

Gutiérrez F, Cooper AH, Johnson KS (2013) Identification, prediction, and mitigation of sinkhole hazards in evaporite karst areas. Environ Geol 70(4):1463-1478

Kaufmann G (2014) Geophysical mapping of solution and collapse sinkholes. J Appl Geophys 111:271-288

Kidybiński A (1982) Basics of mining geotechnics. Wydawnictwo Śląsk, Katowice (in Polish)

Kuniansky EL, Weary DJ, Kaufmann JE (2015) The current status of mapping karst areas and availability of public sinkhole-risk resources in karst terrains of the United States. Hydrogeol J 24(3):613-624

Malinowska A, Matonóg A (2017) Sinkhole hazard mapping with the use of spatial analysis and analytical hierarchy process in the light of mining-geological factors. Acta Geodyn Geomater 14(186):159-172 2 )

Mellett JS, MacCarillo BJ (1996) A model for sinkhole formation on interstate and limited access highways. with suggestions on remediation. Int J Rock Mech Min Sci Geomech Abst 33(2):A85

Papadopoulou-Vrynioti K, Bathrellos GD, Skilodimou HD, Kaviris G, Makropoulos K (2013) Karst collapse susceptibility mapping considering peak ground acceleration in a rapidly growing urban area. Eng Geol 158:77-88

Sałustowicz A (1956) An outline of rock mass mechanics. Wydawnictwo Śląsk, Katowice (in Polish)

Scarborough JA (1996) Risk and reward: pipes and sinkholes in east. Tenn Int J Rock Mech Min Sci Geomech Abst 33(2):A74

Strzałkowski P (2015) Mathematical model of forecasting the formation of sinkhole using Salustowicz's theory. Arch Min Sci 1:63-71

Strzałkowski P (2017) The proposal of predicting formation of sinkholes with an exemplary application. J Min Sci 1:53-58

Strzałkowski P, Tomiczek K (2015) Proposal of a methodology assessing the risk of sink holes formation in mining areas. Int J Min Sci Technol 25(1):85-89

Xiao H, Kim YJ, Nam BH, Wang D (2016) Investigation of the impacts of local-scale hydrogeologic conditions on sinkhole occurrence in East-Central Florida, USA. Environ Earth Sci 75:1274

Xua J, Heb J, Zhang L (2017) Collapse prediction of karst sinkhole via distributed Brillouin optical fiber sensor. Measurement 100:68-71

Publisher's Note Springer Nature remains neutral with regard to jurisdictional claims in published maps and institutional affiliations. 